\title{
Geographical range of melon ladybird Epilachna chrysomelina $F$. in conditions of Zeravshan valley, Uzbekistan.
}

\author{
$B$. Fayzullaev*, and $A$.Suyarova \\ Samarkand State University, Department of Ecology and Life Safety, 140104 Samarkand, Uzbekistan
}

\begin{abstract}
This article is devoted to the study of the geographical distribution, as well as the biology and ecology of the melon ladybug (Epilachna chrysomelina F.), a dangerous pest of melons and gourds in the conditions of the Zerafshan Valley of Uzbekistan. Studying of the biology of the melon ladybug and the development of measures to combat it is currently particular important in the Zerafshan Valley in connection with the development of large tracts of land. The conditions of the newly developed lands make it possible to successfully cultivate, along with cotton, valuable melons and gourds. However, the biology of the pest in the conditions of the Zarafshan Valley of Uzbekistan has not been sufficiently studied and effective measures to combat it have not been developed. The control measures recommended to date are largely outdated and need to be improved. The melon ladybug (Epilachna chrysomelina F.) is widespread in the farms of Samarkand and Bukhara regions of the Zerafshan valley and in some areas of Jizzakh and Syrdarya regions of Uzbekistan, but it is not found in the same numbers and damages the melons and gourds to varying degrees. Within certain geographic limits, mainly due to climatic factors, Epilachna chrysomelina F. currently has an intermittent, lacy character of distribution.
\end{abstract}

\section{Introduction.}

Melon growing is one of the largest branches of agriculture in Uzbekistan.

Melons are more profitable than vegetable crops. Most vegetable farms earn large incomes from high melons yields. Gourds, in particular watermelons and melons, are very nutritious, dietary and very rich in vitamins, mineral salts and enzymes necessary for the human body.

Medical properties of pumpkin are well known. It enhances excretion of water and salt (sodium chloride) from the body. As a good diuretic, pumpkin does not irritate the kidneys. Therefore, it is recommended for diseases of heart and blood vessels, accompanied by edema. In medical and preventive nutrition, pumpkin is useful for people suffering from stomach diseases, when they have easy diet. It is also advised to use it for inflammatory processes and gout. Pumpkin can be used to make many delicious and nutritious dishes.

\footnotetext{
* Corresponding author: boymurodov1971@mail.ru
} 
The seeds of gourds contain valuable edible oil. Pumpkin seeds are especially rich in fat ( 35.6 to $47 \%$ ), and some varieties are sometimes grown for oil. They contain a lot of protein, and in terms of oil content they are superior to sunflower. Fresh seeds contain a resinous substance, which kills intestinal parasites, therefore they are used against various tapeworms. Melon seeds contain 23 to $35 \%$ fat, and watermelon seeds - up to $25 \%$. They are used less frequently for oil extraction [1].

Melons and gourds are a good foregoer of crops such as alfalfa, cabbage, potatoes, tomatoes, root crops and onions under irrigated agriculture, and on dry land they are good predecessors of winter and spring wheat and barley, increasing their yield by 100 percent or more. One of the pros of melons is their cultivation on dry land. It is especially worthy to pay attention to development of a rainfed melon growing in Samarkand and Kashkadarya regions $[2]$.

Fruits of melons and gourds also have a great fodder value.

Uzbekistan currently exports and provides a number of countries around the world and Central Asia with gourds. There is a full opportunity for export here, and most importantly, the fruits of many varieties of melons and gourds are well transportable and they can be kept fresh for a long time.

Abrupt increase in the yield of melons and gourds is achieved by creating new highyielding varieties, improving agrotechnical methods for growing melons. Control of pests and diseases is of paramount importance in increasing the yield of melons and gourds.

The most malicious, specific pest of melons and gourds in the areas of the Zeravshan Valley, Uzbekistan (in Bukhara and Samarkand regions), as well as in Tajikistan and Turkmenistan, is the melon ladybug Epilachna chrysomelina F. It significantly put the brakes on the development of melon growing in our republic. Melon growing annually bears great losses from this pest. Sometimes farms refuse to sow melons because of the harmfulness of the melon ladybug [3].

Research work on the study of biology of melon ladybug and development of measures to combat it is currently acquiring particular importance in the Zeravshan Valley in connection with the development of large tracts of land. Conditions of the newly developed new lands make it possible to successfully cultivate, along with cotton, valuable melons and gourds. However, biology of the pest in conditions of the Zarafshan Valley, Uzbekistan has not been sufficiently researched and there have not been developed effective measures to control it. Currently recommended control measures are largely outdated and need to be improved. There are very few studies on the biology and distribution of the melon moth in modern conditions; in fact, we could only find a study of the geographical distribution and harmfulness of the melon moth in the newly developed lands of the Karshi steppe [4].

Our research work is devoted to the study and development of measures to combat this pest in the areas of its most harmful activity in the Zeravshan Valley.

\section{Places and conditions of the research.}

Our research was conducted in two areas of the Zeravshan Valley, Uzbekistan, which differ in their soil-climatic and other peculiarities, namely: in Samarkand and Bukhara regions, where the melon ladybird is of great economic importance. The route survey was made in Jizzakh and Sirdarya regions.

In this area, the melon ladybird mainly damages the crops of melons and gourds in the areas adjacent to the Zeravshan basin.

Main field experiments on the research of biology of melon ladybird were done and measures to control it were taken concerning the crops of melons and gourds in the Pastdargom and Pakhtachi districts of Samarkand region. 
The research area has a high culture of agriculture, there are land, water and human resources. But it should be noted that a high yield of melons and gourds can be obtained subject to high agricultural technology, first of all, by fighting against agricultural pests melons and gourds, aphids and spider mites.

The research of melon ladybug was conducted by us in 2015-2019 on the farms located in Samarkand region. During this period, we made a trip to Bukhara region in order to establish susceptibility of plants to melons and to determine geographical distribution of this pest.

In addition, at the same time, a route survey was carried out in Jizzakh and Sirdarya regions. In each district, selectively 2-3 farms were examined, where they are engaged in the production of melons and gourds.

In the mentioned areas, melon ladybird was found in various numbers.

\section{Methods for research of biology and ecology of melon ladybug.}

The geographical range of melon ladybird in the districts of Samarkand region, as well as in a number of districts of Bukhara region, was established by means of a route survey.

Boundaries of the range of melon ladybug and possible expansion of its range were determined by the method of climogram and rectangle of favorable conditions.

Percentage of plants, leaves and fruits affected by the melon ladybird was established by examining all plants in the samples. Samples were taken when passing the plots along two diagonals at a distance of 50 meters from each other, a total of at least 20 plants, depending on the size of the plot.

The coefficient of harmfulness of melon ladybug, depending on amount and duration of the pest's residence on the plants, was established by isolating the melons with gauze and replanting various numbers of beetles and larvae of melon ladybird under the isolators.

The experiment had two controls in which the bushes were covered with gauze and left without gauze. Control with gauze cover was established in order to establish the effect of gauze on plant growth and development.

Pollinating bees were artificially planted in the isolators to pollinate the plants. In the control without gauze, the flowing melon beetles were systematically collected in order to prevent damage to plants by beetles and melon beetles.

The experiments were carried out in two and three times.

The isolators were kept until the end of the harvest.

The yield obtained from each plant was weighed and compared with that of the control plant.

The wintering sites of the melon ladybug were established by biological survey. The surveys were carried out in the fields - on crops of melons, cotton, corn, alfalfa, vegetables, cereals, vineyards, in orchards, as well as in the boundaries of fields, at the bases of trees in gardens and on protective tree plantations, roadsides, in the cracks of duvali (walls).

At each survey site, at least 50 samples were taken. The sample size is $0.25 \mathrm{~m}^{2}$. The survey dates are January, February, March and December.

In order to establish the timing of the appearance of melon beetles in spring, from March 1, daily observations were carried out in the fields where melons and other crops were sown, as well as on weeds. On the days when the melon ladybug appeared, meteorological conditions were noted, especially temperatures, according to the data of the nearest meteorological stations. In addition, under laboratory conditions, we determined the air temperature at which the wintering melon beetles become mobile and begin to feed.

The egg-laying sites of melon ladybird were determined by observation in the field, as well as in cages. 
Dynamics of oviposition and fertility of the female melon ladybird were determined by observations in cages and by weekly counts in the fields.

In early spring, after the awakening of the melon ladybug, from the moment the beetles mated, they were caught in pairs (female and male) and put into the cage for observation. The beetles ate melon leaves in the cages, which changed every day.

Half-liter jars with gauze lids were used as cages, and individual melon leaves in the field were isolated with gauze bags.

The eggs laid were counted daily before changing the feed; eggs were destroyed after counting.

Oviposition was observed before the beetles left for hibernation or before their natural death.

In a similar way, the fecundity of females and the dynamics of their oviposition were determined in all generations of the melon ladybird.

During the counting, the air temperature in the cages, as well as atmospheric precipitation and wind, were simultaneously recorded.

In order to establish the dynamics of the number of beetles and larvae in the fields, observations were made of the development of the melon ladybird from the moment it appeared on melons in early spring until it left for wintering. The counts were carried out every week at a certain time of the day, on 20 melon and cucumber plants in each plot. In this case, the number of eggs, larvae, beetles and pupae of the melon ladybird was counted. Observations were carried out on early, middle and late crops of melons and watermelons.

\section{Results of the research.}

Route surveys conducted in 2015-2019 in order to establish geographical distribution of the melon ladybird in Zeravshan valley showed that it is found in Pakhtachi, Narpay, Kattakurgan, Nurabad, Pastdargom districts of Samarkand region and melon-growing regions of Bukhara, Jizzakh and Syrdarya regions. In these areas, melon ladybug is not found in the same numbers and damages the melons and gourds to varying degrees. Degree of infestation of melon crops by melon bug in seasons of its maximum number was recorded according to a three-point system: weak infestation - no more than 5 beetles were found on 10 plants, medium - no more than 10 beetles were found on 10 plants, strong - more than 10 beetles were found on 10 plants.

Melon ladybug, as is known from the literature [5], penetrates to the north only slightly north of Samarkand and is not a mass pest near the borders of its distribution.

Inclusion of the former Syrdarya region in the Epilachna chrysomelina F. range is a clear misunderstanding. Climatic conditions of Fergana, Syrdarya, Tashkent regions are not favorable for its development [6].

Climograms made for Samarkand and Bukhara regions covering Zeravshan valley show that the meteorological conditions of the winter months are especially unfavorable for the melon ladybird in Bukhara region. The rectangle of favorable conditions for the melon ladybug does not cover the bioclimogram compiled for Bukhara region from December to April, and the pest is oppressed by precipitation in these months, and insufficiently high temperatures in December, January and February (Fig. 1).

In Samarkand region melon ladybug is found in sufficient numbers to damage melons and gourds, the temperature conditions are quite favorable for it, but as revealed by bioclimatic analysis, precipitation from December to early May inclusively is too abundant for it. 

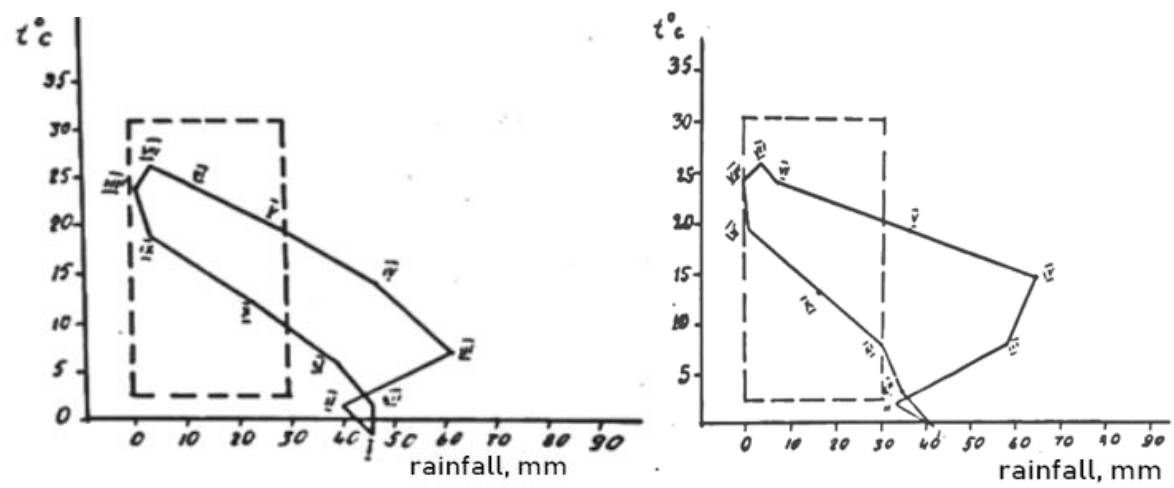

Fig.1. Climograms of Bukhara region (left) and of Samarkand region (right)

Restrictions on the distribution of any species of insects may depend not only on the influence of climate [7].

The influence of climatic, orographic, topographic, soil, and biotic factors on the geographical distribution of insects is known. This complex of factors is considered to be primary, in contrast to secondary factors - anthropomorphic, associated with human activity.

According to Dobrovolsky B.V. [7], restrictions on the spread of insurmountable obstacles in the form of water spaces and mountain ranges are of lesser and not universal importance, they mainly affect the distribution of insects between large areas of land.

However, the biology of the pest in conditions of the Zarafshan valley of Uzbekistan has not been sufficiently studied and effective measures to combat it have not been developed. Control measures recommended to date are largely outdated and need to be improved.

As it can be seen, neither the mountain ranges nor the seas were an obstacle to the spread of Epilachna chrysomelina F. in various regions of the Zeravshan valley.

Under conditions of the Zeravshan valley, this insect is common on all soil varieties where melons and gourds are cultivated. Here, it did not have any catastrophic diseases or parasites and predators that could expose it to complete extermination even in small areas. Of the biotic factors, only the presence of forage plants has a powerful effect on the distribution of Epilachna chrysomelina F.

Therefore, within certain geographic limits, mainly due to climatic factors, Epilachna chrysomelina F. currently has an intermittent, lacy character of distribution.

\section{Conclusion.}

Importance of Central Asia as a center for autochthonous species and the formation of insects was well shown in the research of O.L.Krijanovsky [8].

All of the above gives grounds to assume that the melon ladybird belongs to the autochthonous species in the Zeravshan valley, the center of formation of which is Central Asia, Asia Minor and Iran, the more wild types of pumpkin plants are now found in the named places, sometimes the melon ladybird also feeds on them.

In case of allochthonous origin of Epilachna chrysomelina F., it is nevertheless necessary to make a conclusion about its very ancient penetration into the Zeravshan valley. However, there is no sufficient cause to deny possibility of penetration of melons and gourds into the Zeravshan valley from the south, through Surkhandarya and Kashkadarya regions, Uzbekistan.

Melon ladybug (Epilachna chrysomelina F.) is widespread in the farms of Samarkand and Bukhara regions which cover the Zeravshan valley and in some districts of Jizzakh and 
Sirdarya regions, Uzbekistan. Climatic conditions cause the lacy nature of the spread of the gourd moth in the Zeravshan valley.

\section{References}

1. N.I. Balashov, G.O. Zeman, Vegetable growing (Ukituvchi, Tashkent, 1961)

2. A. Bakiev, Placement, current level and prospects for the development of melon cultivation in the Uzbek SSR: PhD thesis in economic sciences (Tashkent, 1968)

3. A. Kh. Igamberdyev, Bachchia moth (E. chrusomelina F) as a pest of melon crops in the south of Uzbekistan: PhD thesis in biological sciences (Tashkent, 1967)

4. T. Tilavov, A. Urakov, G. D. Kudratov, Innovative development, 2(7), 78-79 (2017)

5. V.V. Yakhontov Pests of agricultural plants and products of Central Asia and their control (Tashkent, 1953) PhD thesis in

6. G.G. Jacobson, Beetles of Russia and Western Europe (Petersburg, 1905)

7. B.V. Dobrovolsky, Range of harmful insects (Centers and zones of greatest harm) (Moscow, 1959)

8. O. L. Krijanovsky, Composition and origin of the terrestrial fauna of Central Asia (mainly based on material on coleoptera) (Nauka, Leningrad, 1965) 